\title{
O discurso espacial como instrumento da produçáo capitalista do espaço: experiências em Sáo Paulo e Barcelona
}

Fabiana Valdoski. Universidade de São Paulo, São Paulo, Brasil.

RESUMo | O discurso espacial tornou-se fundamental para a execução das políticas de espaço que buscam inseri-lo nos circuitos da acumulação através da metamorfose das morfologias de bairros populares e periféricos. Tais discursos incorporam novos elementos devido a sua necessidade permanente de reelaboração, pois os conflitos surgidos ao longo do avanço dessas políticas espaciais corroem argumentos de legitimidade, e estes são alçados à composição de álibis que reponham sua condição pretérita de coerência e coesão. Entre estes recentes álibis incorporados aos discursos espaciais, temos aqueles pautados em reivindicaçôes como as de melhorias infraestruturais e do meio ambiente, transformando, contraditoriamente, a qualidade das matrizes discursivas dos movimentos sociais em instrumentos de uma prática espacial que promove a valorização de lugares em detrimento da apropriação. Isto resulta na produção de uma ideologia do espaço que escamoteia os mecanismos de segregação empreendidos pelas políticas de espaço.

PALAVRAS-CHAVE | geografia urbana, política urbana, segregação.

ABSTRACT | This paper aims to examine how spatial discourses have become key elements for the implementation of spatial policies that seek to insert space into the circuits of accumulation through the reshaping of the spatial morphology of outlying, low-income neighborhoods. Such discourses integrate new elements due to their need of endless reformulation, because the conflicts that emerge with the progression of such spatial policies erode the legitimacy of such arguments. The latter then integrate justifications that reinstate their previous coherence and cohesion. Among such recent justifications incorporated into spatial discourses are those that stem from social demands, such as infrastructural enhancement and environmental protection. In doing so, such discourses transform the discursive matrices of social movements and collective actions into instruments for spatial practices that promote, in some areas of the city, gentrification at the expense of appropriation.

KEY WORDS | urban geography, urban policy, segregation.

Recibido el 3 de julio de 2012, aprobado el 19 de febrero de 2013

E-Mail: valdoski@usp.br

Uma primeira versão deste artigo foi apresentada no Encontro da Associação de Pós-Graduação em Geografia (ANPEGE) em 2011 (UFG -

Goiânia) e é fruto da pesquisa de doutorado defendida em dezembro de 2012, financiada pela Fundaçăo de Amparo à Pesquisa do Estado de São Paulo - FAPESP. 


\section{Introduçáo}

Esa preocupación en el manejo de la impresión ajena ha sido la clave de su éxito a la hora de vender-literalmente y a lo largo y ancho del planetala imagen de una ciudad paradigma de todos los éxitos concebibles, pero de una ciudad que no existe, ni ha existido nunca, que sólo es esa imagen que de ella se vende, un mero decorado, una vitrina, un espejismo tras el que lo que se agitan son otras cosas muy distintas de las que las politicas de promoción y las campañas publicitarias muestran.

(Delgado, 2010, p. 12)

Os conflitos no espaço urbano capitalista, decorrentes das diferentes estratégias daqueles que visam à reproduçáo da vida com acento no uso, e daqueles que o concebem enquanto negócio para a acumulação com a finalidade da troca, são uma regra em sua produção. Como consequência dos embates, as estratégias dos sujeitos envolvidos vão se transformando enquanto condiçáo necessária da relaçáo de poder que se pretende estabelecer sobre a produçáo daquele espaço. Estas mudanças internas e nas formas das estratégias váo sendo reveladas por meio das práticas socioespaciais empreendidas no lugar e este último, concomitantemente, traz à análise a justaposição de açóes, bem como os níveis e dimensóes da produção espacial. Nessa direção, este artigo pretende apontar algumas reflexóes acerca dos conflitos urbanos surgidos no momento de implantação de políticas de espaço, destacando o papel das representaçóes criadas para atenuar as contradiçóes intrínsecas ao processo de produção capitalista. Assim, consideramos que as políticas de espaço em debate se alicerçam, fundamentalmente, em um elemento central -o discurso espacial- contido nas propostas de intervenção urbanística com o objetivo de criar a ilusão dos "consensos".

Partimos da ideia elaborada por Henri Lefebvre em sua obra, na qual compreende que o espaço ganha centralidade na reprodução da acumulação capitalista no século Xx e segue aprofundando sua importância como mercadoria e instrumento político neste início do século XXI. Por tornar-se central, muitas são as estratégias empreendidas no sentido de impor uma determinada conformação a ele e de permitir a minimização das barreiras na obtenção de lucros e rendas. No corpo dessas estratégias, há as representações criadas para dar coerência e coesão às açôes e que se compóem como uma linguagem, que na prática socioespacial aparece como um discurso. Os planos urbanísticos capitaneados em grande parte pelo Estado, como açóes intraurbanas e que integram o corpo das estratégias com a finalidade de transformar o espaço em objeto produtivo, produzem um discurso específico, aquele espacial, legitimando intervençôes.

Este processo de construção de um discurso espacial para legitimar açóes que integrem o espaço urbano ao circuito produtivo, pôde ser observado a partir de cidades inseridas em diferentes contextos, como Barcelona e Sáo Paulo. A primeira é exemplar em sua condição de produção de um discurso espacial, que produziu um pensamento único e do qual poucos autores apontaram criticamente sua elaboração e uso (Benach, 1992; Perez, 1992). Em um avassalador processo de transformação urbana, levado a cabo desde meados da década de 1980, Barcelona lança um 
modelo de crescimento baseado em grandes eventos internacionais e promove um urbanismo dito "participativo" e "inclusivo", comandado pelos partidos de esquerda na Catalunha (Espanha) e assentado na ideia de diminuir a pobreza urbana e redefinir a economia da cidade.

Neste período, poucas eram as vozes dissonantes que questionavam a imagem construída da cidade "pós-moderna” e exemplo para saída de crises originárias do processo de desindustrialização de Barcelona. Todavia, em meados da década de 1990, esta representaçáo de modelo bem sucedido começa a ruir e, nos anos 2000, a contestação torna-se generalizada, seja no âmbito acadêmico, seja na sociedade civil. Mesmo abaladas as estruturas, persistiram e ainda persistem as políticas de espaço, principalmente em lugares e eixos cuja centralidade está na valorização. Porém, para tanto, o discurso espacial, presente e necessário ao processo de elaboração e execução destas políticas, vai adquirindo novos matizes para a legitimação diante da sociedade.

Por outro lado, na cidade de São Paulo, e em um contexto de país do capitalismo periférico, também se tecem políticas de espaço modelares, destacadamente nos lugares mais dinâmicos da integraçáo do espaço ao circuito mercantil e financeiro e de grande evidência nos anos 2000. A passagem de uma metrópole industrial para a de serviços recoloca o papel do espaço, transformando-o em uma raridade do ponto de vista de seu potencial produtivo e, portanto, as qualidades da raridade surgem como justificativas para empreender determinadas políticas de espaço. Assim, muitas destas políticas são concebidas no plano da representação como soluçóes a problemas cruciais à metrópole, quando, de fato, se efetivam como equaçóes para os negócios. Nesta reflexão, ao tratar de São Paulo, referimo-nos às raridades relativas às áreas de lazer e às ambientais, pois porçóes significativas do espaço urbano passam por transformaçóes de usos e funçóes, como as margens do rio Tietê ao norte do município de São Paulo ou as margens das represas Guarapiranga e Billings, legitimadas principalmente pelo discurso espacial ligado ao meio ambiente, a partir do qual se propóe grandes parques lineares às custas de um número elevado de moradores desapropriados destes lugares.

O resultado destas açóes estatais revela um profundo conflito entre aqueles que lutam por continuar nos lugares de reprodução de suas vidas e as práticas do Estado que vão inserindo-os aos circuitos do intercambio, reatualizando processos de segregação socioespacial. Nessa direção, perguntamos primeiramente como estas políticas de espaço adquiriram e ainda possuem a legitimidade e robustez exigidas para se realizarem, mesmo que alavanquem processos que segregam? Como elas conquistaram a legitimação perante a sociedade?

A hipótese central é que se concebe um discurso espacial calcado em elementos críticos do atual período da urbanização e que, em grande parte, estáo expressos em reivindicaçóes dos movimentos sociais e açóes coletivas de grupos da sociedade civil. Estas reivindicaçóes, historicamente exigidas pela sociedade, tais como as melhorias infraestruturais com a inserção de equipamentos nas periferias ou a emergência/urgência da preservação ambiental, contraditoriamente são incorporadas ao discurso por meio da transformaçáo das mesmas em álibis que legitimam as políticas de espaço, já que repóem a coesão e coerência a partir da usurpação da forma da linguagem daqueles que lutam pelo espaço para o uso. Todavia, essas políticas de 
espaço não promovem as possibilidades de apropriação do espaço, como apregoado por aqueles sujeitos da reivindicação, mas tendem a realizar a privatização deste com uma sutil representação do "consenso".

Muitas destas políticas de espaços postas como objeto da presente reflexão, originaram-se de demandas sociais diante da precariedade da vida como, por exemplo, melhorias da moradia e do bairro em Barcelona ou uma política de meio ambiente e lazer em São Paulo. No movimento de urbanização capitalista, o processo de espoliação e expropriação da maior parte da população produziu morfologias precárias, escassez de recursos, falta de infraestrutura, impossibilidade de acesso à moradia, problemas com poluição de mananciais, compondo o quadro de crise da cidade. O crescimento urbano, impulsionado pela industrialização, caminhava pari passu com o aumento da precariedade da vida da populaçáo. Em Barcelona, a cidade se produzia com as morfologias das chabolas ${ }^{1}$, compreendidas como o fenômeno do barraquismo. Como alternativa, se produziu no início do século xx uma política de moradia para os operários que se dirigiam às cidades industriais, e que se denominou de Casas Baratas. Mas, a lógica de compra de terrenos baratos para se construir casas pequenas, em número elevado, impunha a circunstância do bairro ser construído longe do centro da cidade, em lugares sem infraestrutura de transporte, equipamentos urbanos, etc. Por sua vez, São Paulo também produzia uma periferia com loteamentos irregulares, favelas, sem transporte público e infraestrutura urbana nas áreas onde se concentram os mananciais que abastecem a maior parte dos habitantes da região metropolitana.

Estas condiçóes precárias, empreendidas pela lógica tendencial da produção do espaço urbano capitalista, náo se realizaram sem obstáculos. Internamente ao processo de aumento da precariedade surgiram organizaçóes, movimentos sociais e açóes coletivas que empreenderam lutas constantes, reivindicando o mínimo necessário, de modo que, ao longo de anos melhorias foram sendo incorporadas aos bairros periféricos. Simultaneamente, a concretização das demandas por infraestruturas e melhorias urbanas escassas nas cidades, juntamente com o avanço do processo de urbanização, iam incorporando valor a estes espaços objetos de luta, qualificando-os e compondo um quadro atraente para futuros investimentos, quando novas frentes potenciais de valorização são exigidas. Este movimento do processo nos coloca diante de uma contradição do espaço: ao empreender a luta por melhores condiçóes, a populaçáo inserida precariamente na cidade conquista melhorias para a reprodução da vida, as quais valorizam o espaço. Esta valorizaçáo tende, no movimento da totalidade da metrópole, a atrair políticas de espaço que náo estáo mais atreladas diretamente às reivindicaçóes e sim, às açóes intimamente ligadas à troca, empreendendo novamente a segregaçáo socioespacial. Porém, em um contexto como este, os novos planos urbanísticos caracterizados como uma política de espaço usurpam da história pretérita de luta pelo espaço os elementos para se legitimarem. 
Em um movimento de incorporação de porçóes da cidade aos circuitos de valorização, aquela área considerada periférica é inserida no eixo produtivo devido às qualidades incorporadas pelas conquistas e reivindicaçóes para o uso. Porém, em determinado momento, quando a expansão dos negócios urbanos busca novas frentes de rentabilidade, os lugares tendem a ser cooptados, de maneira que um discurso torna-se o instrumento que legitima as políticas de espaço sequenciais. Tais políticas alicerçam e estruturam os novos espaços, homogeneizando-os para a realização dos lucros e rendas nesta nova centralidade econômica e segregando aqueles com rendas incompatíveis aos novos valores da propriedade da terra e que, durante anos, lutaram por melhores condiçóes de habitabilidade.

Das novas políticas de espaço a serem implantadas, emerge um conflito entre os moradores e a ordem distante (Estado), conflito este considerado ainda mais profundo por incorporar, nas estratégias do espaço-mercadoria, a ideologia discurso espacial - na qual há a inserção dos primeiros como integrantes destes projetos. É este processo contraditório e conflitante que envolve a produção do espaço urbano que observamos em Barcelona e em Sáo Paulo, e mesmo se tratando de cidades inseridas em contextos distintos, verificamos um caráter homogêneo das estratégias econômicas atreladas ao Estado, principalmente no que tange à representaçáo. Ou seja, em Barcelona a justificativa de remodelaçáo de um bairro antigo e de perfil operário - Bon Pastor - inserido no novo eixo de valorização (La Sagrera) alicerça seu discurso espacial sobre a participaçáo da sociedade civil e as melhorias que viriam com uma nova morfologia espacial, substituindo as antigas casas existentes e atendendo às reivindicaçóes por décadas postas pela Associaçáo de Vizinhos (Asociación Vecinal de Bon Pastor). Por outro lado, em São Paulo, parte da antiga favela Nova Guarapiranga (zona sul do município), que conquistou a urbanização e regularizaçáo fundiária em uma luta de aproximadamente três décadas pela segurança da posse, se vê imersa em um processo de desapropriação em nome da qualidade ambiental necessária à população da metrópole. Tal desapropriação se efetua para a construção de um grande parque linear em torno da represa da Guarapiranga.

Destes dois cenários apresentados, podemos recuperar a hipótese inicial cujo ponto de articulação reside no fato de problematizar os processos de segregação socioespacial em países distribuídos diferentemente no quadro do desenvolvimento desigual, mas, em ambos os casos, as muitas estratégias de valorização se legitimam sutilmente através de um discurso espacial que incorpora as demandas da população e que, posteriormente, se transforma em mecanismos de segregação. Observamos que os lugares em análise estáo situados, em suas respectivas metrópoles, nos eixos de valorização recente, o que converge para a hipótese secundária desenvolvida anteriormente, ou seja, as conquistas proporcionaram (proporcionam) uma melhoria das condiçóes infraestruturais. Entretanto, estas qualidades espaciais vão promovendo a inserçáo nas porçóes de possível valorização, pontuando a necessidade da permanente resistência em uma cidade capitalista. 


\section{Políticas de espaço e discursos espaciais}

Muitos autores e especificamente geógrafos, apontam o movimento da inserção da produção do espaço urbano como elemento central na reproduçáo capitalista, conduzindo à constituição de uma trama de negócios no processo de urbanização (Lefebvre, 2006; Carlos, 1994; Damiani, 1999; Tello, 2006). E é por meio deste processo que tendemos a uma nova dinâmica espacial, a qual redefine as relaçóes sociais à medida que a urbanização capitalista se estende pelo globo. Como explicou Carlos (2006), uma das relaçôes redefinidas é aquela entre Estado e espaço:

Através das políticas públicas que orientam os investimentos em determinados setores e em determinadas áreas da metrópole, com a produção de infraestruturas e 'reparcelamento' do solo urbano através da realização das chamadas operações urbanas e da chamada requalificaçâo de áreas - principalmente centrais - através da realização de 'parcerias' entre prefeitura e os setores privados que acabam influenciando e orientando essas políticas (p. 47).

A esta orientaçáo dada na articulação entre o privado e o público, com acento sobre a reproduçáo do capital, as açóes hegemônicas sobre o espaço se caracterizam como políticas que conduzem a um processo de homogeneização deste mesmo espaço, que necessita, ao se transformar em mercadoria, tornar-se um equivalente enquanto condição abstrata para a efetivação da troca.

Para tanto, na produção de um espaço intercambiável, as açóes estatais também adquirem a centralidade por meio do planejamento que, ao longo de seu desenvolvimento, vai ganhando categorias até o ponto de explicitar sua finalidade de tornar o espaço produtivo quando é adjetivado como estratégico. Sua atuação se materializa em políticas de espaço (Lefebvre, 2006) estratégicas para a valorização, na medida em que são um conjunto de açóes que redefinem usos, funçóes e estruturas com o direcionamento do fluxo de investimentos a determinados lugares da metrópole e o constituem, por fim, como um equivalente.

Essas políticas de espaço, capitaneadas pelo Estado e que reúnem um conjunto de açóes, contêm características especificas em seus diferentes planos como o econômico, o político e o social. Segundo Lefebvre (2002), esta ação leva às últimas consequências as estratégias "lógicas" em que este poder se exerce como vontade e representaçáo. Ou seja:

Como vontade: o poder do Estado e os homens que detêm esse poder têm uma estratégia ou estratégias políticas. Como representação: os homens de Estado têm uma concepção política ideologicamente justificada do espaço (ou uma ausência de concepção que deixa o campo livre aos que propóem suas imagens particulares do tempo e do espaço) (p. 77).

$\mathrm{Na}$ legitimação das estratégias, há a inclusão de um plano de representação fundamental para que se realize a açáo violenta empreendida pelo Estado, já que estas políticas aprofundam as contradiçóes advindas da urbanização ao promover os processos da desigualdade e segregação socioespacial. Em várias obras, Henri Lefebvre tratou de aludir à importância destas representaçóes -com destaque ao papel da 
linguagem- que se constituíram, enquanto instrumentos, para dar corpo às cadeias lógicas que embasam uma ideologia fundamental de reproduçáo da sociedade.

Compreendemos, portanto, que na busca da coerência e da coesão como tentativa de escamotear os conflitos e contradiçóes, para dar robustez e legitimidade a estas políticas, a linguagem se apresenta como preponderante na prática urbana estatal, no sentido de constituir uma ideologia do espaço. Chegam ao planejamento, na ilusão da transparência (Lefebvre: 2006, p. 41), compreendendo o espaço como aquele objeto vazio de conteúdo e de intencionalidade, capaz de ser concebido como bem se convém ao apenas reordená-lo.

A linguagem, como expressão da representação, aparece enquanto mecanismo que tenta envolver a imaginação individual e os simbolismos coletivos, ao compor uma gramática que contenha uma gama de ligaçóes que mascarem as pressóes sociais. Ela toma de assalto o espaço como instrumento estratégico e, na prática urbana, se realiza-se como um discurso espacial que, sutilmente, apresenta subsistemas que obscurecem o próprio espaço, ao não colocar em relevo as contradiçóes do espaço social. Esses subsistemas se constituem em uma rede de álibis apresentados pelo discurso espacial, os quais adquirem uma abrangência que transita desde os discursos de crescimento, passando pelos ambientais e mesmo pela pobreza urbana. O discurso transforma-se em um instrumento da coerência e ganha importância no decurso da história. Porém, cabe ressaltar que mesmo na tentativa de sufocar os conflitos oriundos da tendência da coerência e coesão atribuídas (ou tentativa de atribuir) ao espaço, eles persistem na produção do espaço urbano, ainda que em latência.

Por isso, podemos observar e compreender que os discursos espaciais realizam a tentativa de ocultar o espaço social e seu campo de conflito, mas não o fazem em sua plenitude, e o resultado é que este embate exige a permanente produção de elementos para compor a cadeia lógica do discurso. Também verificamos que há nuances nos discursos de São Paulo e de Barcelona, posto que se referem a realidades urbanas desiguais pela divisão territorial do trabalho entre uma cidade de um país periférico e outra do centro do capitalismo. Contudo, em nossa reflexáo que tem por objetivo ambas as cidades, há dois pontos que as unem. O primeiro, atrelado ao caráter de mundialização da sociedade urbana pela égide da reprodução cumulativa que traça estratégias de transformação do espaço em mercadoria e, o segundo, as resistências também se fizeram mundiais e as reivindicaçóes, mesmo que distintas, apontam as contradiçóes da sobreposição do valor de troca sobre o valor de uso.

$\mathrm{Na}$ integração do espaço à acumulação, ambas as metrópoles vão buscando novos motores de reproduçáo do capital quando começam a deixar de ser o lócus da indústria e se inserem nos processos financeiros, com acento no imobiliário. Barcelona inicia sua produçáo ao tentar transformar-se em cidade modelo para eventos e turismo, produzindo uma imagem vendível a toda ou qualquer pessoa que esteja disposta a usar seu tempo de lazer em um consumo programado do espaço. Além disto, ao acompanhar a guinada dada pela própria Espanha, empreende um ritmo avassalador de investimentos sobre o mercado imobiliário e de infraestruturas. São incorporadas à cidade as políticas de espaço para grandes revitalizaçóes, novos equipamentos e, ao mesmo tempo, aumentando a mobilidade da antiga população moradora. Benach (2009) informa que para realizar este intento "[e]l conjunto 
de estrategias emprendidas fueran siempre acompańadas por un más que notable despliegue de comunicación, tanto de lo conseguido como de lo pretendido".

O discurso espacial estava fundamentado sobre a necessidade de uma economia urbana embasada em outra vertente que substituísse a indústria, com melhorias infraestruturais para a população e a possibilidade da participação da sociedade civil na elaboração e execução das políticas de espaço. Um elemento chave é compreender que neste momento da história do país, década de 1970-1980, se passava uma série de processos de mudanças na economia, na política e na sociedade espanhola e, especificamente, na cidade catalá. Ocorria no país um processo de desindustrialização e, ao mesmo tempo, de democratização.

Todavia, será neste cenário que Barcelona compóe os discursos que até hoje alicerçam as açóes do Ayuntamiento (Prefeitura), destacando o papel destas políticas de espaço como de interesse coletivo. De acordo com Tello (2006):

Quando se fundamenta o discurso de uma prática sobre o bem comum de um coletivo amplo e indefinido, como é o conjunto de habitantes de uma cidade, se desvanecem rapidamente os cidadãos, as pessoas e, em seu lugar, aparece a cidade como um ser com necessidades e vida própria. Quanto maior o coletivo de cidadão, mais rapidamente esses se diluem no interesse geral, teoricamente fundamentado na racionalidade e na lógica do comportamento econômico, e mais rapidamente cobra vida o ente cidade, sobretudo em se tratando de grande metrópole (p. 431).

Esse discurso espacial, que em determinado momento incorpora a ideia do interesse coletivo, continua com seu dinamismo se reelaborando constantemente, já que os conflitos se aprofundam conforme as políticas de espaço vão avançando. Porém, mesmo ele não consegue mascarar que os preços dos aluguéis se elevaram, a manutenção da propriedade daqueles que ainda permaneceram no bairro também aumentou, a remoção de famílias foi muito volumosa e as promessas sobre o futuro daquele lugar não se cumpriram. Como observado pelo Taller contra la violencia inmobiliaria y urbanistica (2006):

Obviamente, todas estas transformaciones urbanísticas son presentadas como grandes mejoras para los Barrios, todas vienen acompañadas de promesas de zonas verdes, equipamientos y algún que otro piso social. Promesas que, muchas veces, no se cumplen nunca o sólo en parte, pero que sirven para granjearse el apoyo de las asociaciones de comerciantes y de alguna que otra entidad clientelar del Ayuntamiento radicada en la zona, todo ello acompañado por campańas propagandísticas en los medios de comunicación local. En cambio, las críticas de los vecinos sobre los aumentos de los precios de los pisos y de los alquileres y a la destrucción del tejido social, son desechadas como un efecto secundario no deseado, que escapa a las posibilidades de intervención del Ayuntamiento y de otras administraciones públicas implicadas (p. 62).

O discurso espacial apresentado para os lugares que vai se inserindo nos mais recentes circuitos da valorizaçáo, elabora-se com a reproduçáo de elementos anteriores, mas também com a produçáo de novos. Neste percurso, muitos dos conflitos latentes eclodem. 
Já em São Paulo, cidade pertencente ao capitalismo periférico e que se situa diferentemente na divisáo territorial do trabalho, ele surge com traços muitos mais profundos da desigualdade e, concomitantemente, aparecem as estratégias mais ferozes das políticas de espaço. Nelas, as desapropriaçôes são uma regra, e mobilizam a números consideráveis da população. As justificativas que as legitimam também se compóem sobre um discurso espacial com álibis, que muitas vezes, são as partes críticas do conteúdo do processo de urbanização. Um destes álibis é a questão ambiental.

Como necessidade pleiteada pelo coletivo, o meio ambiente torna-se elemento inquestionável nos discursos espaciais. Tais discursos, quando compreendidos no aspecto da situação geográfica da cidade de São Paulo, ganham potência ainda maior pelo fato de que, no processo da urbanização paulistana, a população espoliada e precarizada em sua condição de trabalho ocupou os lugares considerados como os mais frágeis ambientalmente, destacadamente as áreas de proteção permanente (APP), produzindo as morfologias de favelas.

Esta condição transformou a questão ambiental em discurso que legitima a expulsão da populaçáo espoliada quando estes lugares transformaram-se de interesse ao mercado imobiliário formal, pois as APPs podem se tornar parques lineares nas margens de córregos e, assim, pequenas áreas verdes se somam às qualidades dos novos loteamentos ou das revitalizaçóes, incorporando aquilo que é raro na cidade. Novamente, as promessas se direcionam para as melhorias da populaçáo urbana e escondem os mecanismos de expropriação da mesma. Conforme Rodrigues esclarece (2011), 'O ideário do 'bem comum' e o que se espera para o 'desenvolvimento sustentável', é que seja o alicerce do poder da ideologia que oculta a essência e toma a aparência como realidade"(p. 214) e, neste viés, o meio ambiente entra como alicerce da valorização pela raridade na metrópole e também como álibi para ocultar a segregação socioespacial na produção do espaço capitalista.

Mas, no contexto apresentado acima, um aspecto importante merece ser destacado. Tanto as questóes relacionadas às necessidades de melhoria infraestruturais, quanto às de preocupação ambiental, estão presentes nas reivindicações da sociedade, uma vez que, na realidade, são partes da problemática urbana. Contudo, nas permanentes transformaçóes pelas quais o discurso espacial passa para se fortalecer, ele pode tomar as reivindicações da sociedade e transformá-las, no âmbito das representaçóes, como finalidade das políticas de espaço propostas no sentido da troca.

Ao destrinchar estas mesmas políticas, no âmbito do lugar, desvendamos uma trama estratégica de realização do espaço como mercadoria, impondo àquela população que vive no lugar, novos constrangimentos e que tendem a novas formas da segregação socioespacial, tais como, aumento de aluguel, inserçáo no mercado financeiro por meio de hipotecas, desapropriaçóes e despejos forçados.

\section{Das políticas de espaço na metrópole à contestação no lugar}

Como já foi explicitado, dois lugares são destacados em nossa análise: o bairro de Bon Pastor em Barcelona (Figura 1) e a antiga favela Nova Guarapiranga em São Paulo (Figura 2). Ambos localizam-se nos vetores de valorização das respectivas metrópoles, La Sagrera (nordeste) e represa Guarapiranga (vetor sudoeste), e 
apresentam atualmente um conflito gestado na justaposição de políticas de espaço, acarretando novos processos segregatórios ocultados e legitimados por discursos espaciais. O primeiro, pelo discurso da participaçáo e de melhorias infraestruturais e, o segundo, pelo discurso ambiental; ambos apoiados sobre a justificativa do interesse coletivo.
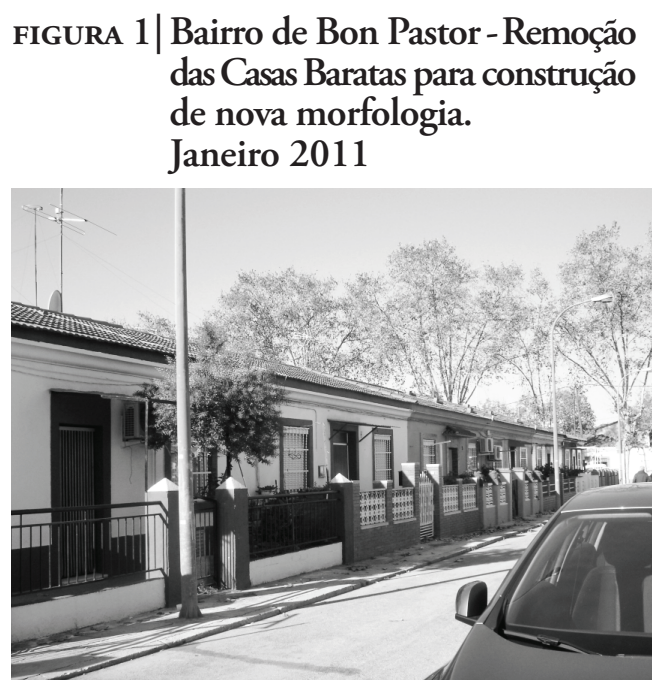

FIGURA 2 | Nova Guarapiranga - Remoçáo de Parte das Casas Autoconstruídas para construçáo de um parque e uma ciclovia. Maio 2011

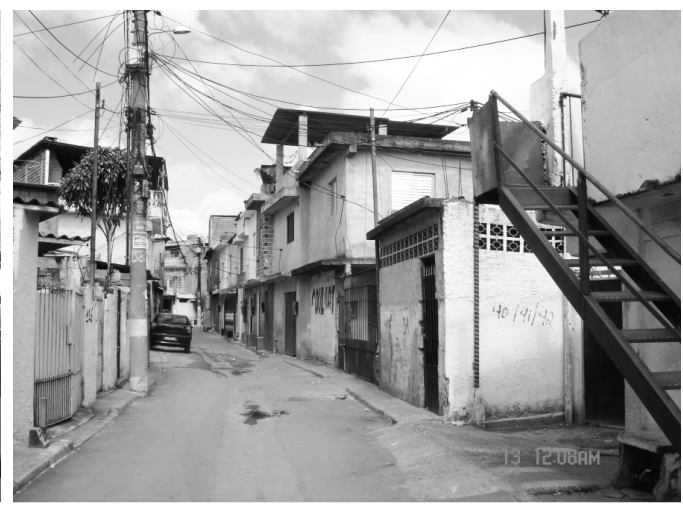

Nova Guarapiranga - desapropriaçóes e a erosáo da luta pela segurança da posse $\mathrm{Na}$ zona sul de São Paulo, os lugares entre as represas Guarapiranga e Billings estiveram predominantemente ocupados, até meados da década de 1960, por sítios e chácaras, bem como haviam se transformado em área de lazer para uma população com maior poder aquisitivo, recebendo construçóes como clubes de campo e, principalmente próximo à Guarapiranga, casas de alto padrão. Nas décadas de 20 e 30 do século xx já eram objeto de um plano de valorizaçáo, com a projeçáo de um bairro nos moldes da cidade jardim, equipamentos como autódromo, tentativa de implantação de hotéis, isso tudo no intuito de transformar a regiáo na área de lazer do paulistano com maior poder aquisitivo. Contudo, estes planos elaborados na primeira metade do século xx foram frustrados, sendo apenas parcialmente executados. No plano da paisagem, restou somente a morfologia de casas de proprietários abastados e dos clubes, alguns dos quais até hoje funcionam.

$\mathrm{Na}$ década de 1970 uma significativa transformação ocorre. No intuito de preservar as áreas de mananciais para garantir o abastecimento de água do município, foi promulgada a legislaçáo ambiental (Lei Estadual 898/75 e 1.176/76) que impunha muitas exigências aos processos de parcelamento do solo daquela porçáo da metrópole, recuando os recursos para inserçáo de infraestrutura e provocando um relativo desinteresse do mercado imobiliário. Este fato levou a um barateamento dos terrenos na regiáo das represas, ao mesmo tempo em que outras partes da cidade de São Paulo tornaram-se objeto de investimentos do mercado imobiliário formal. Somados a estes fatos, a população, em um quadro de maior espoliação, com 
rebaixamento de salários e desemprego elevado, não conseguia ter acesso à casa por meio do aluguel ou compra, e a única forma possível de morar seria através da ação de ocupação dos lugares com menor possibilidade de expulsão, como nas margens das represas Billings e Guarapiranga.

No início dos anos 1980 inicia-se a produção da favela Nova Guarapiranga, que se localiza nas margens da represa de mesmo nome. Sua ocupaçáo ocorreu por meio dos "balóes mágicos", formato dos barracos, que se tornou o modo como ocupavam a área como forma de resistência às remoçóes que a Prefeitura fazia continuamente. Como a maioria das favelas, os primeiros barracos eram de madeira e, apenas após o recuo da Prefeitura em retirar a população da área, é que se iniciam as construçóes em alvenaria.

Em um quadro de agravamento da capacidade hídrica de Sáo Paulo, ela transformou-se em objeto de uma política de espaço chamada Programa Guarapiranga, que em conjunto com a Prefeitura de Sáo Paulo e o governo do Estado, objetivavam promover a recuperação da qualidade das águas da represa com financiamento internacional - BIRD. Para tanto, foram promovidas melhorias infraestruturais por meio de urbanização de favelas e adequaçóes dos bairros, com implantaçáo de rede coletora e de tratamento de esgoto. Dentre as favelas que passaram por este processo estava a Nova Guarapiranga, que em 1997 teve a finalização das obras. Um dos itens deste programa também era aquele relativo à regularização fundiária como medida preventiva para o adensamento das favelas, o qual foi efetivado após 10 anos das obras de infraestrutura. De acordo com a concepçáo estabelecida pelo programa, as áreas irregulares apenas seriam controladas a partir de sua legalização, já que assim, o poder público poderia fiscalizar as açóes ilícitas.

Simultaneamente, outras camadas legais foram sendo adicionadas ao perímetro da represa no intuito de protegê-la e foram normatizando a Nova Guarapiranga. Uma das leis era a 9.866/1997 que dispunha sobre as diretrizes e normas de proteção e recuperação das bacias hidrográficas dos mananciais. Nela, haviam sido classificadas as áreas de recuperação ambiental, nas quais Nova Guarapiranga se enquadrava. Somada a essa lei, em 2006, se promulga a Lei Específica da Guarapiranga (Lei Estadual no 12.233/2006) criando a Área de Proteção e Recuperação de Mananciais da Bacia Hidrográfica do Guarapiranga. Dentro dela, se definiu também as subáreas de urbanização consolidada e é reiterada a condição de Nova Guarapiranga como um núcleo efetivamente reconhecido, em que se poderia implantar a política de regularização fundiária de interesse social.

Na confluência dessas leis e também do Estatuto da Cidade e da Medida Provisória 2220/2001, após 10 anos de finalização das obras de infraestrutura, o lugar é contemplado pela regularização fundiária dos imóveis existentes. Essa demora não se fez sem razão, a polêmica em regularizar áreas de proteção ambiental esteve sempre como um álibi na justificativa da remoção das favelas, mesmo quando estas já foram objeto de intervençóes.

Atualmente, a Nova Guarapiranga possui dois núcleos, totalizando mais de 300 famílias que receberam no ano de 2008 o título de concessão de uso (CUEM Concessão de Uso Especial para Fins de Moradia e CDRU - Concessão de Direito Real de Uso) dos lotes em que vivem para garantir a segurança da posse. 
Após a regularização da favela, um novo fato ocorre, o qual demonstra as contradiçôes de uma política pública quando uma porção da metrópole entra nas tramas de interesses da valorização imobiliária. Pelo álibi da questão ambiental, propôs-se um grande parque linear na extensáo da orla da represa Guarapiranga, que seria composto por um complexo de sete parques e interligados por uma ciclovia. Segundo informativo da Prefeitura:

De forma geral, a ideia é anexar novas áreas a esses parques para que, unidos, sejam transformados em um único parque que circunde toda essa porção da represa, formando entâo a chamada 'Praia de São Paulo'.

A partir de um diagnóstico realizado pelo poder público municipal, através da Secretaria Municipal do Verde e do Meio Ambiente, considerou-se que a história de avanço da urbanização da regiáo da Guarapiranga levava a decretar que esta porção tinha uma "vocação" turística, ambiental e de lazer. Esta visão é expressa no Diário Oficial da Prefeitura:

A represa Guarapiranga tem vocação natural ao lazer e ao turismo, e o programa de recuperaçáo da orla, além do claro objetivo de preservação ambiental, visa o resgate de atividades comerciais que possam gerar emprego e renda para a regiáo, sem causar danos ambientais à represa. Dessa forma, todo o programa prevê a ordenação das ocupaçôes ao longo da orla, mantendo clubes náuticos, as marinas, os restaurantes, os quiosques, os estaleiros, escolas de esportes náuticos e procurando atrair ainda outros empreendimentos ambientalmente responsáveis.

O documento elaborado pelo poder público municipal sobre esta vocaçáo, que depois é divulgado oficialmente, legitimou a ação de elaboração de uma política de espaço que reuniu três Subprefeituras (Capela do Socorro, M'boi Mirim e Parelheiros), como também a Secretaria Municipal de Governo, a própria Secretaria do Verde e Meio Ambiente e a Secretaria Estadual de Saneamento e Energia e Secretaria Estadual de Meio Ambiente. De acordo com a Subprefeitura de Capela do Socorro, o objetivo do projeto seria:

Revitalizar e desenvolver a vocação da regiáo da Orla do Guarapiranga para o esporte, lazer e turismo, de forma ambientalmente sustentável, possibilitando emprego e renda à população local, ampliando a conscientização e melhorando a qualidade de vida.

O poder público inicia a implantação dessa política de espaço sobre vários terrenos que estão localizados entre a Avenida Robert Kennedy, atualmente rebatizada de Avenida Atlântica, por meio de açóes de desapropriação ${ }^{2}$, concessão de uso para licenciamento do parque num convênio com a EMAE e incorporação de áreas já

2 Segundo a Prefeitura "A área foi desapropriada para ampliar os parques municipais que fazem parte do Programa de Revitalização da Orla da Guarapiranga, uma parceria entre Estado e Prefeitura que vem implantando parques, ciclovias, grades de proteção e calçadóes ao longo da orla da represa de Guarapiranga. Ela se soma a outros $700 \mathrm{mil} \mathrm{m} 2$ de áreas verdes que foram desapropriados e conveniados pela Empresa Metropolitana de Água e Energia (EMAE) à Prefeitura de São Paulo para a implantação dos parques de defesa da Guarapiranga”. Prefeitura desapropria terreno às margens da represa Guarapiranga. Disponível em: http://www.sampaonline.com.br/ reportagens/golfcenter2010nov28.php. 
pertencentes à Prefeitura. Sua estratégia se constrói, fundamentalmente, na composição de um discurso espacial assentado em um aspecto crítico do processo de produção do espaço urbano e que, atualmente, configura uma das raridades produzidas pelo processo de urbanização contemporâneo, a questão ambiental e a escassez de áreas de lazer.

Essa política transforma o meio ambiente em um álibi para legitimar a prática de desapropriação de áreas com propriedade privada especificamente capitalista, como os bairros constituídos há décadas, bem como justifica a reintegração de posse dos terrenos pertencentes à Prefeitura onde se localizam os moradores de baixa renda. A prioridade, como apresentada no excerto do Diário Oficial, é de atividades comerciais "compatíveis" com a "sustentabilidade", mas claramente mediada pelas relaçóes mercantis, como os comércios e clubes associados à paisagem da represa.

O discurso espacial, que legitima a implantação do conjunto de parques na Orla da Guarapiranga, está assentado no fato do interesse geral da população da metrópole na medida em que traz lazer e recuperação visual, além da educação ambiental. A seguinte informação foi concedida por um dos responsáveis pelo projeto ${ }^{3}$ :

Quando nós conseguirmos terminar toda a ocupação, a orla inteira vai ser um parque com vários núcleos e qual é o objetivo. É realmente recuperação visual da margem, da mata ciliar, criar área de lazer.

Ela ainda acrescenta que:

O ganho que a cidade vai ter é o ar mais limpo, é menos poluição, é a área de lazer enorme e maravilhosa. A região ganhou muito. Ficou 20, 30 anos sem ninguém olhar pra cá e de repente a gente está olhando e trazendo este tipo de equipamento sofisticado. Parque, a gente pensa que não, mas no desenvolvimento urbano dá dignidade a essas pessoas.

Contudo, o objetivo da política de espaço é explicitada também na mesma fala, quando a arquiteta diz que:

Foi criado um novo eixo, qualquer governante gosta de criar a sua marca, ele faz uma ponte, faz um viaduto. No caso do Kassab também, ele está fazendo o metrô, mas ele foca muito nesse projeto, é a menina dos olhos dele. Ele está investindo muito nisso porque é a criação de cartão postal. É um cartão postal novo da cidade em uma área que sempre esteve ai. Além de toda a parte ambiental que a gente está trabalhando, a parte política esta se aproveitando e mostrando, olha só. Parece que ele que fez a represa. É uma política realmente de criação de novos marcos.

O discurso espacial explicitado acima dilui, no plano da representação, as pessoas que vivem na margem da represa, colocando-as em uma condição de invisibilidade diante do grande empreendimento que irá construir um "novo cartão postal” para a cidade e, principalmente, argumenta-se que Sáo Paulo receberá um parque que restituirá a "dignidade" perdida. Esse discurso adquire credibilidade na medida em que espaços de lazer e verdes são uma raridade na cidade de São Paulo. Tal condição

3 Entrevista realizada com arquiteta responsável pelo projeto de revitalização da Orla da Guarapiranga em maio de 2011. 
de raridade justifica uma desapropriação massiva dos moradores daquele lugar e estes, por sua vez, quando questionam essa política de espaço, são caracterizados como aqueles que impedem o "desenvolvimento" da cidade.

Este empreendimento do poder público em curso está reatualizando as formas de desapropriação, que não afeta somente a população beneficiada pela regularização fundiária, mas ainda imóveis particulares e áreas de clubes. Porém, a ênfase dada neste momento da reflexáo recai sobre aqueles que enfrentam, cotidianamente, as camadas de expropriação e que necessitam transgredir e resistir para criar as condiçóes para morar na cidade. As consequências desta prática espacial do Estado se realizam, ainda mais perversamente, àqueles que lutaram por continuar em uma área mais valorizada, como nesta parte da represa Guarapiranga, pois mesmo com o título de concessáo de uso, que lhes propiciou valores um pouco mais volumosos em relação às indenizaçóes, certamente não existirá a possibilidade de compra de outro imóvel no mesmo lugar e que esteja inserido nos padróes formais pelos quais lutaram.

Portanto, percebemos, junto com Rodrigues (2011), que:

Os discursos sobre o meio ambiente têm a finalidade de permitir a continuidade da produção de mercadorias e garantir a apropriação privada das riquezas, reafirmando a ideologia dominante (p. 211).

\section{Bon Pastor - Metamorfose da morfologia espacial e elevação dos custos de manutençáo da moradia}

Em Barcelona, na esteira de sua construção simbólica sobre o discurso espacial, no sentido de promover um clima favorável à implantação das políticas de espaço, está o bairro de Bon Pastor. Ele se localiza na área que atualmente é a mais dinâmica do município, La Sagrera, e como o próprio diretor de urbanismo do Ayuntamiento ${ }^{4}$ expôs, pertence hoje às áreas mais estratégicas de Barcelona.

Como o modelo Barcelona se construía através de um discurso no sentido de:

Conseguir que Barcelona se converta en una metrópole europea empredendora con incidência sobre la macrorregión en la que se situa geograficamente, que disponga de una calidade de vida moderna y equilibrada y este enraizada en la cultura mediterrânea (Raventós apud Benach, 1993, p.342).

... a prática do poder público de decretar áreas obsoletas revelou-se como regra de avanço das políticas de espaço. Em entrevista, o diretor de urbanismo do município apresenta como esta prática se realiza e qual o seu conceito: "pegar partes da cidade obsoleta derrubá-las e voltar a construir sobre elas. E as pessoas que vivem no bairro seguem sendo as mesmas 5 .

Inserido nesta lógica, o Bairro de Bon Pastor é sumariamente decretado como obsoleto e, portanto, passível de ser derrubado para estar com as condiçóes necessárias para condizer com os novos equipamentos em seu entorno. A sua história é varrida para comportar uma nova morfologia adequada com as valorizaçóes decorrentes de

Ayuntamiento equivale no Brasil ao nível municipal de poder - Prefeitura Municipal. Entrevista realizada com Jaume Barnada em janeiro de 2010. 
investimentos oriundos do próprio orçamento do Ayuntamiento e até os da União Europeia. Cabe lembrar, ao recuperar a produção do lugar, que Bon Pastor surge, em 1929, como uma morfologia espacial, consequência da legislação específica para soluçóes de moradias (Casas Baratas) ${ }^{6}$ àqueles migrantes que vinham trabalhar na indústria, isto é, se compóe de um conjunto de quase 800 casas de perfil operário. $\mathrm{Na}$ época, o lugar se situava em uma porção de Barcelona carente de recursos de toda a ordem (infraestrutura, transporte, equipamentos urbanos, mobiliário urbano) e, em decorrência disto, uma série de reivindicaçóes é pleiteada junto ao poder público, desde as melhorias das casas até a necessidade de infraestrutura para melhoria do bairro.

No momento de decretação do bairro como obsoleto, estas demandas históricas dos moradores são incorporadas pelo discurso espacial, fortalecendo a política de espaço proposta no ano de 2003. Chamada de Plano de Remodelação e aprovada pelo Patronat Municipal de l'Habitatge, instituição municipal, proprietária e gestora das casas baratas, propóe a total derrubada da antiga morfologia e prevê a implantaçáo de prédios de apartamentos com o dobro da metragem das antigas unidades habitacionais. Este plano ocorreria em 4 fases e as transferências das famílias realizar-se-iam aos poucos. Como apresenta Delgado (2010):

De pronto, alguien, en algún sitio, decide algo que cambiará la forma y la vida de un barrio. Primero se lo declara 'obsoleto', luego se redacta un plan perfecto, se elaboran unos planos llenos de curvas y rectas, se hace todo ello público de manera atractiva - dibujitos y maquetas - y se promete una existencia mejor a los seres humanos cuya vida va a ser, como el lugar, remodelada. A continuación se proponen ofertas de realojamiento - que siempre perjudican a quienes no podrán asumir las nuevas condiciones que indirectamente se les imponen -, se encauzan dinámicas de participación - orientadas, de hecho, a dividir a los vecinos afectados - y después se continúa sometiendo a ese pedazo de ciudad a un abandono que ya lo venía deteriorando, para disuadir a las victimas-beneficiarios de la transformación de su urgencia e inevitabilidad (p. 47).

O discurso espacial que alicerça esta prática do Estado, além de incorporar a questão de melhorias infraestruturais ao alegar que eram demandas da Asociación Vecinal devido às condiçóes insalubres das casas, também acrescenta um determinado aval dado pelo processo dito "participativo" na aprovação do projeto. Logo, no jogo discursivo, a opinião dos moradores se divide, cedendo terreno à aceitação de tal projeto e que é referendado em um plebiscito. O grupo "A Barcelona a Participació Canta" avalia que:

As Casas Baratas sáo consideradas Viviendas de Protección Oficial que funcionam sob o regime de aluguéis e geridas por instituiçóes municipais. Em Barcelona, a responsabilidade estava com o Instituto Municipal de la Vivienda, atual Patronat Municipal de la Vivienda. A origem destes bairros na Espanha advém da legislaçáo do início do século xx (1911) e visava a resolver o problema da moradia dos operários e da classe média baixa, todavia, as casas baratas foram na época construídas em lugares periféricos das cidades sem quase nenhuma infraestrutura e equipamentos adequados e, portanto, em terrenos baratos. 
El referéndum a través del cual se cualifica de 'participativo' el proyecto fue en primer lugar 'no vinculante', y luego no fue celebrado con las garantías de seguridad y con la información necesaria para que su resultado pueda considerarse válido.

A divisão estava posta entre os vizinhos, pois havia aqueles que queriam aderir ao projeto e aqueles que gostariam de continuar com suas casas, principalmente pelas estratégias praticadas pelo poder público de oferecer, diferentemente aos moradores, as condiçóes da mudança de uma morfologia a outra e sem esclarecer, contundentemente, os termos do novo contrato. Outros mecanismos somam-se a este, como angariar o consentimento e aceitação do plano de remodelaçáo por parte da Asociación Vecinal de Bon Pastor que, devido à mesma história de lutas, possui significativa credibilidade diante dos moradores. Assim, aprovado pelo plebiscito dito participativo, o projeto dá seus primeiros passos e, aqueles conflitos latentes, aparecem no momento dos despejos violentos para iniciar a primeira fase e preparar o terreno para a "moderna" tipologia. De acordo com entrevista realizada com um grupo de arquitetos e sociólogos que se reúnem para repensar o projeto e expor as condiçôes de como estavam sendo executadas as fases da obra (grupo Repensar Bon Pastor), observa-se que desde o princípio o Ayuntamiento náo explicitava claramente as condiçôes desta transferencia, e o discurso espacial se legitimava firmemente pelas melhorias de habitabilidade. Duas eram as possibilidades de transferência no novo contrato: os moradores iriam para os novos apartamentos enquanto inquilinos, condição na qual já estavam, ou enquanto compradores, ao efetuarem uma hipoteca em um banco. Entretanto, os termos dos contratos de aluguel, bem como do de compra, não revelavam os mecanismos de expropriação contidos neste rearranjo. ${ }^{7}$

Do ponto de vista do contrato de aluguel, haveria já uma subida dos preços ao entrar no novo apartamento, abocanhando uma parte dos baixos salários daquela população, como também, se celebraria por apenas 5 anos o prazo dos contratos com possibilidade de renovaçáo com ajustes de preços para além dos estabelecidos ao ano (anualmente se faz os reajustes pelo IPC - índice de preços ao consumidor). Aqueles que optaram pela compra, ingressaram nos mecanismos da financeirizaçáo com a hipoteca do apartamento que, como consequência, traz implicaçóes profundas ao contrair uma dívida por décadas e submeter-se aos aumentos frenéticos dados pelas taxas bancárias. Inúmeras são as implicaçóes deste processo, as quais vão desde o próprio rompimento das relaçóes de vizinhança até a privatização do solo público, ao ceder a propriedade ao privado por meio de hipotecas (bancos). Como informado pelo grupo Repensar Bon Pastor, já ocorrem os primeiros despejos

7 As consequências da transformação da morfologia espacial e dos novos contratos assinados são explicitadas em artigo da International Alliance of Inhabitats - "La familia Molinar Bermejo, madre, hija y tres nietos pequeños, hace algunos meses no puede pagar al banco las hipotecas, ya que con la crisis todos los miembros activos se han quedado en paro. No han servido de nada las llamadas al Patronato para que se haga cargo de la situación, como les había prometido al momento de la firma del contrato. El banco Sabadell ya ha vendido su piso, y enviado a Maria Rosa Bermejo - el 19 de noviembre de 2009 - una orden de desalojo." (...) "Otros, si no recibieron aún una orden de desalojo, llevan varios meses sin pagar el alquiler, y están desesperadamente intentando resolver la situación negociando con el Patronato. 'Si hubiera sabido que dos años después me iba a encontrar en esta situación, no hubiera firmado la renuncia a mi contrato de renta antigua a 12 euros al mes." Disponível em: http://bit.ly/1dYN5lE. 
promovidos pelos mecanismos das hipotecas, pois as famílias não conseguiram arcar com a manutençấo da nova propriedade, que requer o pagamento da "comunidad" (condomínio), impostos, etc, bem como as taxas mais elevadas dos contratos de aluguel e de compra. A fala do grupo nos apresenta as implicaçóes da transformação da morfologia:

... la propiedad, a la hora de hacer gestiones económicas, en las hipotecas el referente no es mas el Ayuntamiento sino si convierte en el Banco Sabadel...

el banco te dá el crédito: en cualquier hipoteca española.. en el momento en qué tú te hipotecas, el piso es del banco. El piso es del banco, y el banco te dá el dinero... como que el banco lo ha comprado al patronato. Entonces el piso es del banco, y la persona tiene que pagarlo, entonces cuando ha finalizado de pagarlo, entonces este piso es de esa persona: mientras tanto es del banco; y si el banco te desahucia, la deuda con el banco la tienes igual. Pierdes la casa pero sigues teniendo la deuda.

hay varios, hay gente que llegó al barrio hace pocos años, y ya pagaban 200 euros, entonces para ellos a lo mejor el cambio no es tan fuerte, comparado que tienen un piso grande; pero otra gente está pagando de toda la vida 50 euros, entonces claro, pasan a pagar 300 o 350, más los gastos de agua, de la comunidad...

No que tange à morfologia construída, o discurso espacial assentado nas melhorias de habitabilidade pode ser questionado, já que as construçóes dos primeiros prédios já apresentam deficiências devido aos materiais utilizados na obra, ou seja, os moradores terão que arcar com novas despesas para reformar os apartamentos.

Neste processo, verificamos que o espaço não tem nada de neutro ou transparente, uma vez que as estratégias possuem uma finalidade que é escamoteada pelo discurso espacial. Como formulado por Manuel Delgado (2010, p. 48):

Un vistazo a su ubicación en el mapa de la ciudad y un paseo por el entorno desvelan inmediatamente las claves de tanta urgencia por borrar del mapa las Casas Baratas del Bon Pastor. A un paso de la nueva centralidad que se proyecta para la Sagrera, con la gran terminal del AVE, el espectacular edificio encargado a Frank Gehry y ese nuevo barrio que seguro que no será para el mismo tipo de humanidad que vivía y habia luchado allí a lo largo de lustros.

Essa estratégia de transformação do espaço em mercadoria produz efeitos perversos aos moradores, como relata Taller contra la violencia inmobiliaria y urbanistica (2006, p. 62):

Solo para nombrar un ejemplo, en el entorno de la futura estación del AVE, los precios de los pisos se han triplicado desde 2002, lo que supone la expulsión de un gran número de vecinos a la primera corona metropolitana, al mismo tiempo que se está dando una actividad frenética de derribos de casas y de nuevas construcciones.

Portanto, verificamos como as estratégias de classe que tomam o espaço para o campo da acumulação, transformando-o em mercadoria, elabora um discurso espacial com elementos das demandas sociais, porém promove novas estratégias de 
segregação socioespacial, muitas vezes difícil de serem reveladas no momento de realização das estratégias. Como posto por Lefebvre (1978), a ideologia mais eficaz é aquela mais sutil e pode muitas vezes estar vinculada ao discurso:

Como todas as instituiçóes, o discurso e a linguagem são polivalentes: eles veiculam necessidades e desejos, poesia e ideologia, símbolos e conceitos, mitos e verdades, mas também condiçôes de poder (estatal), os seus símbolos e as suas palavras-chaves. Contribuem, portanto, para reproduzir as relaçóes de produção.

\section{Consideraçóes sobre a generalização da segregaçáo socioespacial}

Os processos relatados acima envolvem compreender os novos álibis dispostos no discurso espacial e que, ao nível da representaçáo, são fundamentais para as estratégias espaciais da acumulação. Compreendê-lo permite observar a tendência de produçáo do espaço urbano, a qual está assentada fundamentalmente na segregação socioespacial e que, a partir dos conflitos entre o uso e troca, vai adquirindo uma roupagem original, por meio da qual se esconde os mecanismos reais de produção do espaço para a troca. Esta produçáo de um ocultamento do espaço se realiza sob o discurso espacial incorporando, como álibi, o conteúdo das demandas sociais, já que estes são elementos críticos do processo de urbanização contemporâneo e, desse modo, tendem a se transformar na ideologia mais sutil, portanto, potente de se realizar minimizando os conflitos.

Considerado como uma estratégia de valorização do espaço, legitima a homogeneização do espaço atribuindo-lhe condiçóes que o recolocam no circuito da produção. Simultaneamente, ao recobrar uma determinada unidade/coesão/ coerência da propriedade fragmentada dos antigos discursos para a realizaçáo da política de espaço, chega-se à fragmentação do espaço social e que, na produçáo do lugar, foi tecida ao longo das práticas realizadas no entrelaçamento do vivido daqueles moradores. Conformam-se, nessas experiências, exemplos da crise urbana como impossibilidade da apropriaçáo do lugar produzido.

As experiências apresentadas também revelam o papel do Estado na prática urbana, que ao empreender políticas de espaço, alicerçam a produção de uma nova centralidade econômica baseada na transformação da morfologia, resultando na expropriação dos moradores. Isso nos revela que, na cidade capitalista, tanto proprietários e náo-proprietários estáo submetidos às consequentes expulsóes para ceder à transformação do espaço improdutivo para o produtivo.

Os resultados destas políticas de espaço, tais como as descritas, revelam o perpetuar da mobilidade da população precarizada que, não podendo arcar com os custos oriundos da metamorfose das morfologias espaciais ou sendo obrigada a se dispersar pela cidade já que seu lugar de morada foi refuncionalizado, é enredada na trama da valorização que a expropria da vida social estabelecida na produção do lugar. Estamos diante da contradiçáo que está na base dos conflitos urbanos na reproduçáo do espaço, aquela entre a produção socializada da riqueza e sua apropriaçáo privada, seja em um país do centro do capitalismo, seja no pertencente à periferia. Essa contradição se realiza com singularidades em cada lugar, mas as lógicas estratégicas 
de âmbito econômico e político contêm características similares e homogêneas, como é próprio de uma economia globalizada. Simultaneamente, como produto desse processo, há a produção de uma generalização da segregação socioespacial e, ao mesmo tempo, do negativo que resiste a esta tendência, conformada nos conflitos entre as finalidades de uso do espaço.

O papel do discurso espacial baseado no saber técnico e científico tenta encobrir também o negativo. Como regra, o nega também através de estratégias muitas vezes ligadas ao âmbito da linguagem e à produção de uma representação do espaço. Todavia, o negativo está presente, como latência, contendo ambiguidades e contradiçôes, pois está presente no irredutível da vida dos moradores. Ele existe, já que está em jogo a vida ou as condiçóes primárias de viver e se reproduzir. Esse negativo emerge das mais variadas maneiras, bem como de formas mais dramáticas no âmbito do vivido dos moradores.

Dito isto, observamos que o viver na cidade significa, para seus habitantes, permanentemente transgredir e resistir a este processo expropriatório constante e que os arrasta, a cada dia, às periferias mais distantes.

\section{Referências bibliográficas}

Arantes, O., Maricato, E. \& Vainer, C. (2000) A cidade do pensamento único: desmanchando consensos. Petrópolis. Rio de Janeiro: Vozes.

Benach, N. (2009). La economía simbólica de la ciudad: Barcelona como ejemplo. En Barcelona: de ciudad industrial a metrópolis internacional, III Jornadas de Campo de Geografía Económica, Grupo de Geografía Económica. Asociación de Geógrafos Españoles (GGE/AGE). Barcelona, 29 y 30 de junio de 2009.

Benach, N. (1993). Producción de imagen en la Barcelona del 92. Estudios Geográficos (Barcelona), 212, 483-505.

Busquets, J. (2004). Barcelona: la construcción urbanistica de una ciudad compacta. Barcelona: Ediciones del Serbal.

Carlos, A. F. (1994). A (re)produção do espaço urbano. São Paulo: Edusp.

Carlos, A. F. (2006). A segregação como fundamento da crise urbana. In J. B. Silva, L. C. Lima \& E. W. C. Dantas (Orgs.), Panorama da Geografia Brasileira II. São Paulo: Annablume.

Carlos, A. F. (2011). Da 'organização' à 'produção' do espaço no movimento do pensamento geográfico. In A. F. A. Carlos, .M. L. Souza \& M. E. B. Sposito, A produção do espaço urbano: agentes e processos, escalas e desafios. São Paulo: Contexto.

Damiani, A. (1999). A crise da cidade: os termos da urbanização. In A. F. A. Carlos, A. Damiani \& O. L. S. Seabra, O espaço no fim do século: a nova raridade. Geousp Abordagens. Sáo Paulo: Contexto.

Delgado, M. (2010). La ciudad mentirosa: fraude y miseria del "Modelo Barcelona”. Madrid: Catarata.

Lefebvre, H. (1981). Critique de la vie quotidienne III. Paris: L'Arche Éditeur. 
Lefebvre, H. (2006). A produção do espaço. (Trad. Grupo "As (im)possibilidades do urbano na metrópole contemporânea”, do núcleo de geografia urbana da UFMG). $1^{\text {a }}$ versão. Belo Horizonte: s/ed.

Lefebvre, H. (1978). A re-produção das relaçôes de produção. Porto: Publicações Escorpião.

Lefebvre, H. (2002). A revoluçâo urbana. (Trad. Sérgio Martins). Belo Horizonte: Editora UFMG.

Martins, M. L. R. (2006). Moradia e Mananciais: tensão e diálogo na metrópole. São Paulo. Fapesp.

Ribeiro, F. V. A produção do lugar na metrópole paulistana. São Paulo: Labur Edições/GEsp/UsP, 2007. Disponível em http://www.fflch.usp.br/dg/gesp/labur.htm.

Ribeiro, F. V. (2012). A Luta pelo espaço: Da segurança da posse à política de regularização fundiária de interesse social em São Paulo. Tese de Doutorado. Universidade de São Paulo, Departamento de Geografia, São Paulo.

Rodrigues, A M. (2011). A matriz discursiva sobre o 'meio ambiente': produção do espaço urbano - agentes, escalas, conflitos. In A. F. A. Carlos, M. L. Souza \& M. E. B. Sposito, A produção do espaço urbano: agentes e processos, escalas e desafios. São Paulo: Contexto.

TALLER CONTRA LA VIOLENCIA INMOBILIARIA Y URBANÍSTICA. (2006). El cielo está enladrillado: entre el mobbing y la violencia inmobiliaria y urbanistica. Barcelona: Ediciones Bellaterra.

Tello, R. Planejamento urbano: discurso anacrônico, práticas globalizadas. In A. F. A., Carlos \& A. U. Oliveira, Geografias da metrópole. São Paulo: Contexto. 